\title{
Macrurans (Crustacea, Decapoda) from the Lower Triassic (Olenekian) of the Ambilobé area (NW Madagascar).
}

\author{
Alessandro Garassino ${ }^{1}$, Giovanni Pasini ${ }^{2}$ \& Giorgio Teruzzi ${ }^{1}$ \\ ${ }^{1}$ Dipartimento di Paleontologia degli Invertebrati, Museo civico di Storia naturale, C.so Venezia 55, I-20121 \\ Milano, Italy: ${ }^{2}$ Museo Civico dei Fossili di Besano, Via Prestini 5, I-21050 Besano (Varese), Italy
}

Keywords: Crustacea, Decapoda, Triassic, Madagascar

\begin{abstract}
Fossil decapods of the Lower Triassic marine strata of Madagascar are reviewed. These display affiliation to the dendrobranchiates. These include Antrimpos madagascariensis, two species of Ifasya (I. madagascariensis and $I$. straeleni) and Ambilobeia karojoi.
\end{abstract}

\section{Introduction}

Fossiliferous levels within Lower Triassic marine strata to the south/south-west of the village of Ambilobé, c. $150 \mathrm{~km}$ SW of Diego Suarez (Antsiranana, Madagascar) have long been known (Besairie, 1932), Beltan (1996) proposed a Dienerian (Early Triassic) age for the fossil-bearing beds in the Ambilobé area, based on correlation with the Lystrosaurus and Cynognathus zones of the Beaufort Group (Battail et al, 1987). Recently, Yanbin et al. (2002) have studied some conchostracans from this area, and assigned them to Euestheria (Magniestheria) truempyi (Kozur \& Seidel, 1983). In view of the fact that this species has previously been recorded also from the Bernburg Formation (lowermost Olenekian) in the German Basin, we may date the Ambilobé faunal assemblage as Olenekian rather than Induan (Dienerian).

This famous faunal assemblage, which comprises invertebrates (ammonites, nautiloids, bivalves, serpulids, decapod crustaceans, thylacocephalans, cycloids, limulids and conchostracans) and vertebrates (mostly fish and rare amphibians), is found in the westernmost outcrops of a band of sedimentary rocks, roughly between the small villages of Anabo- rano Ifasy in the south west and of Bobasatrana in the northeast.

\section{Results}

The first description of decapod crustaceans from the Lower Triassic of Madagascar is that by van Straelen (1933), who recorded two incomplete specimens from the Ambilobé area, referring both to a new species, Antrimpos madagascariensis. Garassino \& Teruzzi (1995) carried on this study, having available a sample of 400 specimens, in part collected during a field trip in 1989 organised by the Dipartimento di Paleontologia degli Invertebrati del Museo civico di Storia naturale di Milano and in part collected earlier by one of us (GP). In this assemblage, the genus Ifasya Garassino \& Teruzzi, 1995 was recognised, with the species I. madagascariensis (van Straelen, 1933) and I. straeleni Garassino \& Teruzzi, 1995 (Fig. 1).

Recently, Garassino \& Pasini (2002) have studied a single specimen collected from a new outcrop near the village of Bobasatrana. This show certain morphological features, e.g., elongate rostrum without supra- and sub-rostral teeth, strong tooth at base of rostrum, pereiopods I-III with short and stout chelae) that set it apart from species of Ifasya. To contain this species, the genus Ambilobeia Garassino \& Pasini, 2002, was erected (type species: $A$. karojoi Garassino \& Pasini, 2002; see Fig. 1). Only the Late Triassic genus Antrimpos von Münster, 1839 might show certain morphological affinities in the shape of rostrum and body with 

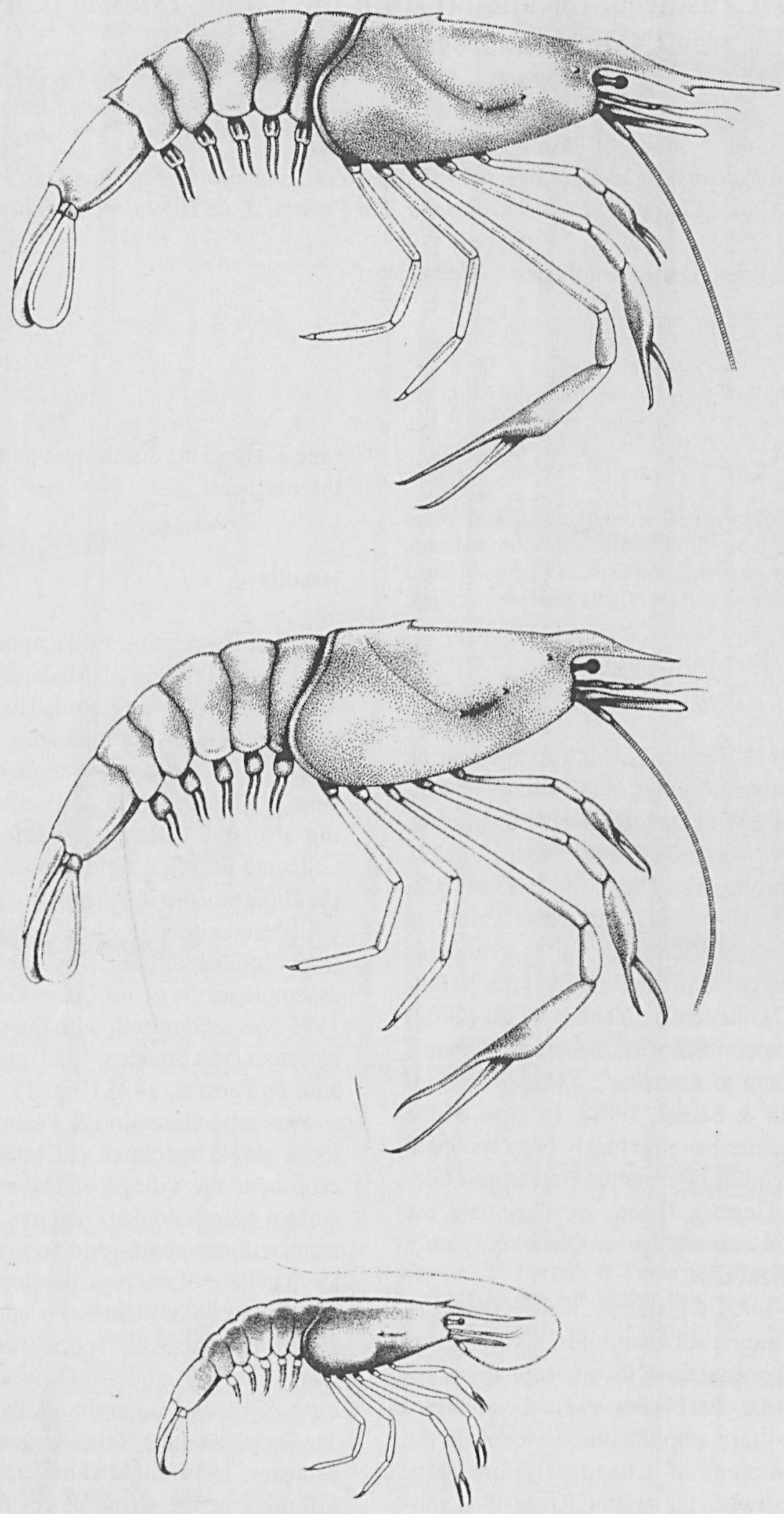
the new genus. However, a rostrum with supra- and sub-rostral teeth, the presence of one strong antennal spine and of hepatic, orbito-antennal and gastro-frontal grooves distinguish Antrimpos from Ambilobeia.

\section{References}

Battail B, Beltan L, Dutuit JM. 1987. Africa and Madagascar during Permo-Triassic time: the evidence of the vertebrate faunas. Geophys. Monogr. 41: 147-155.

Beltan L. 1996. Overview of systematics, paleobiology and paleoecology of Triassic fishes of northwestern Madagascar: 479-500. In: Arratia G, Viohl G (eds). Mesozoic fishes. Systematics and paleoecology. München: F. Pfeil.

Besairie H. 1932. Sur le Permo-Trias marin du nord de Madagascar et l'age du Karroo, C. R. Séances Soc. géol. Fr. 10: 30-34.
Garassino A, Teruzzi G. 1995. Studies on Permo-Trias of Madagascar. 3. The decapod crustaceans of the Ambilober region (NW Madagascar). Atti Soc. it. Sci. nat. Mus. civ. Storia nat. Milano 134: 85-113.

Garassino A, Pasini G. 2002. Studies on Permo-Trias of Madagascar. 5. Ambilobeia karojoi n. gen. n. sp. (Crustacea, Decapoda) from the Lower Triassic (Olenekian) of Ambilobé region (NW Madagascar). Atti Soc. it. Sci. nat. Mus. civ. Storia nat. Milano 143: 95-104.

Straelen V van. 1933. Antrimpos madagascariensis Crustacé décapode de Permotrias de Madagascar. Bull. Mus. r. Hist. nat. Belg. 9(15): 1-3.

Yanbin S, Garassino A, Teruzzi G. 2002. Studies on PermoTrias of Madagascar. 4. Early Triassic conchostracans from Madagascar. Atti Soc. it. Sci. nat. Mus. cìv. Storia nat. Milano 143: 3-11.

Received: 2 March 2003

$\leftarrow$

Fig. 1. Macruran decapod crustaceans from the Lower Triassic of the Ambilobé area, NW Madagascar (from to top to bottom): Ifasya madagascariensis (van Straelen, 1933), I. straeleni Garassino \& Teruzzi, 1995, and Ambilobeia karojoi Garassino \& Pasini, 2002. 